\title{
V-Set Domain-Containing T-Cell Activation Inhibitor 1
}

National Cancer Institute

\section{Source}

National Cancer Institute. V-Set Domain-Containing T-Cell Activation Inhibitor 1. NCI

Thesaurus. Code C106223.

V-set domain-containing T-cell activation inhibitor 1 (282 aa, $31 \mathrm{kDa}$ ) is encoded by the human VTCN1 gene. This protein plays a role in the inhibition of T-cell functions. 